\title{
The Usage of Visum et Repertum (VeR) as A Scientific Evidence in Animal Abuse according to The perspective of The Penal Code (KUHP) and The Law of Criminal Procedure Code (KUHAP) in Indonesia
}

\author{
Bilqisthi Ari Putra, Ignatius.N.S. \\ Pudji H. \\ Forensic Science, Postgraduate School, \\ Universitas Airlangga \\ Surabaya, Indonesia \\ (bilqisthi.ari.putra- \\ 2016@pasca.unair.ac.id)
}

\author{
Haniyah \\ Lecturer, Faculty of Law \\ Universitas Sunan Giri \\ Sidoarjo, Indonesia \\ haniyahkarsa99@gmail.com
}

\author{
Sadjijono \\ Professor, Faculty of Law \\ Universitas Bhayangkara \\ Surabaya, Indonesia
}

\begin{abstract}
Presently, the number of animal abuse cases in Indonesia is increasing but lacks sufficient attention by the public and law enforcement. This situation can be attributed to the lack of understanding of scientific investigation in relation to the evidence in cases of animal abuse. This paradigm often means that the perpetrators escape criminal sanctions, even though the Indonesian Government has provided protection for animal welfare which is regulated in the Penal Code (KUHP) in article 302. The purpose of this study was to describe the functions of Visum et Repertum (VeR) according to the perspective of the Penal Code (KUHP) and the Law of Criminal Procedure Code (KUHAP) in Indonesia. This study was conducted using the normative approach and the use of Visum et Repertum (VeR) as scientific evidence in cases of animal abuse or animal negligence investigations according to KUHAP article 184 and establishing animals as legal subjects. Visum et Repertum does not apply only to humans but also applies to animals in order to prove the presence or absence of criminal acts that occur. Visum et repertum has important role to play; lowering the number of animal cruelty cases in Indonesia with sufficient support from the government and law enforcement.
\end{abstract}

Keywords - Visum et repertum, crime against anaimal, evidence, pembuktian.

\section{INTRODUCTION}

Presently, many people consider that a crime is a deed associated with humans, harming other humans and human victims. This argument is not completely wrong, but we do need to realise that there are other living creatures besides human beings which can be mistreated. In fact, crimes against animals receive less attention, both from the government and the wider community because there is the assumption that crimes against animals do not bring harm to individuals and/or society, therefore there is no need for concern if there is a crime against animals.

The forms of animal abuse that exist encompass all matters that disrupt animal welfare irresponsibly, such as animal abuse/torture, animal organ trafficking, selling animal skin and bones, animal exploitation and animal massacre. Animal crimes committed by humans are varied such as exploiting animals for the benefit of humans by making them commodity workers such as monkey masks that we see a lot, animal fighting, animal shooting, animal burning and massacres.

The existence of obstacles in the process of the Legal Protection of Protected Animals is due to the lack of government or law enforcement's firmness to crack down on these cases. Because of that, many people and legal entities can easily damage the animal's life which consequently makes most animals have an endangered status, and some even already extinct. There is no specific and strong legislation in relation to regulating animal protection at this time, causing animals that should be protected to be treated unnaturally by parties who are responsible for violence against animals. Human consciousness, which means the value or rule of law that is regulated, has not been implemented in this context [2].

Cases of crimes against other animals include topeng monyet, animal hit and run, poisoning dogs and cats, cockfighting, dog fighting and so forth. 
In the interest of law enforcement, there is the need for evidence in the form of visum et repertum as evidence for injury or damage to the victim's body as concrete evidence of a criminal act.

The process of the investigation of criminal cases involving the body, health and human life requires the help of a physician. The assistance of a physician with the application of judicial medical science as set forth in his visum et repertum is absolutely necessary. Visum et repertum functions as a written report for the interest of the judiciary at the request of the law enforcement authorities, and especially by the investigator. Visum et repertum is made by the doctor according to what he sees and discovers on examination of the evidence, bound to his/her medical oath, and on the basis of his/her knowledge. [1]

Visum et repertum made by a doctor based on his/her oath as a written statement in medical science is one of the evidences that can be used to prove the existence of a crime, as set forth in the Criminal Code on humans. It is unclear whether the same visum which is performed on humans can be applied equally to animals to prove the existence of a crime against animals, as a verification attempt in court.

This research attempts to reveal the position and function of visum et repertum as evidence in the case of crimes against animals according to the criminal law system that is in effect in Indonesia.

\section{METHODS}

The author used the Normative Juridical method as the the method of collecting the materials, and for the method of processing/analysing the material. In terms of collecting the materials, this study has used a literature study through researching of books, legislation, articles and various other relevant written documents. Given that this research has used the normative juridical method, the principal data used here is secondary data.

\section{DISCUSSIONS}

The efforts made by law enforcement officers to seek the material truth of a criminal case is asserted in Law No. 4 of 2004 Article 6 paragraph (2) of the Basic Provisions of Judicial Power which reads: "No person shall be punished, except where a court of lawful evidence under the Law obtains the conviction that a person who is held responsible is guilty of an act Accused of himself ". The existence of the provisions of the act suggest that in the process of settling criminal cases, law enforcement officials must be obliged to collect evidence of the criminal cases that it handles.
Some cases of death or animal persecution as above can actually be performed in relation to visum et repertum for animals as evidence of whether there has been a crime on the animal body. Visum et repertum can also be utilised for the benefit of animals. The question is how far the community understands the presence of visum et repertum for animals when it is needed as an attempt to prove that a crime against animals has occurred.

Forms of legal protection against animals and forms of criminal liability for the perpetrators of crimes against animals, as set forth in criminal law books as evidence that the government also regulates animal welfare as set forth in article 302 of the Criminal Code, are as follows:

(1). Threatened with a maximum imprisonment of three months or a maximum fine of four thousand five hundred thousand rupiah for committing a mild persecution against animals:

1. Any person who is unreasonable or surreptitiously purposeful, who deliberately injures the animal or adversely affects his / her health.

2. Any person who is unwise or beyond the limits required to achieve that purpose, wilfully delivers the food necessary for living to the animal, wholly or partly in possession of it and under its control, or to the animal that it obligated to maintain.

(2) If the act causes illness of more than a week or is defective or suffers from other serious injuries, or dies, then the offender is threatened with imprisonment for a maximum of nine months, or a fine of at most three hundred rupiah, due to animal persecution.

(3) If the animal belongs to the guilty party, then the animal may be seized.

(4) An attempt to commit a crime is not punishable.

From the definition above, a crime against an animal whether it is a persecution that causes injuries even to an inadequate or sadistic animal killings - is subjected to threemonth criminal imprisonment and a fine of four thousand rupiah. The problem here is that crimes against animals have never been the focus of attention of the public and the law enforcement. The community is not aware of animal welfare because it is considered to not be important unless the protected animal is protected by the government, despite the fact that the attention of the public is very limited.

In many cases in crimes against animals, visum et repertum has a very important role as written evidence made by a veterinarian about what is seen, against the actual situation based on the investigation with the aim of giving evidence of 
the facts and conclusions as legally valid proof of justice. It is one of the means of proof in imposing criminal penalties or penalties as laid down in article 183 of the Criminal Code:

"That the judge should not impose a crime on a person negligent when with at least two legitimate evidence he obtains the conviction that a criminal act is true and that the defendant is attempting to do so".

The verification process in the trial occupies a very important place in the examination of a case. From the results, the verification process will determine the fate of the defendant. The definition of the proof itself is not expressly set forth in the Criminal Procedure Code even though there is a provision of evidence. In response, some opinions of the jurists on the definition of evidentiary evidences, among them proving inherent terms and guidelines on the ways, is justified by the law to prove the indigent of the defendant. Evidence is also a provision that authenticates the evidence justified by the Act and may be used by the judge to prove the guilt of the indictment [7]. The law of proof "constitutes part of a criminal procedural law that regulates legitimate instruments of evidence [8]. The system embraces the proof, terms and procedures of the proof that shall be authorised by the judge to accept, reject and judge as proof. "The judge used the evidence of guilty wrongdoing [7]

So in the case of the proof of the presence or absence of the fulfilment of criminal elements in a criminal act, then at least two valid evidences and Visum et repertum by a veterinarian regarding the crime against an animal is necessary.

One of the valid evidences according to KUHAP [6] as set forth in article 184 KUHAP reads:

(1) valid evidence is:

1. witness testimony

2. expert testimony

3. letter

4. instructions

5. defendants' testimony

Article 187 mentions the letter as set out in article 184 (1) of the Criminal Procedure Code which reads as follows: "The letter as referred to in article 184 (1) letter c shall be made into the oath of office or affirmed by the oath: the minutes of the event and other letters in the form. Authorised by an authorised or competent public authority which contains the hearing of the incident or circumstances heard, seen or experienced by himself, accompanied by a clear and unequivocal reason for the explanation".
The completeness of the Visum Et Repertum in the case of the defendant examined by the judge shall be submitted to the prosecutor who has since been handed the file of the "Pro Yustisia" case by the investigator of the public prosecutor. This individual has tried to prove the file in the hearing so that the judge is convinced of the guilt of the defendant [6]. If, in the hearing, there is enough existing evidence without the Visum Et Repertum, then Visum Et Repertum is not absolutely necessary. The judges will still use Article 183 of the Criminal Procedure Code, except for speedy inspections. Since Visum Et Repertum is valid evidence, if it is contained in the file of the case, then the Visum Et Repertum must be mentioned and considered by the judges in their decision. Therefore, a Visum Et Repertum in a criminal case file is not evidence (vide: Article 194 KUHAP) [6] because the Visum Et Repertum is made (published) not on the basis of seizure (seizure) or the confiscated objects of a person [4].

From the clause stated above, it is clear that visum et repertum for animal crimes is something that a veterinarian should do if there is an animal crime and is a valid item of (corpus delicti) evidence in court. Animals are also creatures made by God. So in this case, the awareness of all elements of society to participate in caring about animal welfare and animal evil is a form of moral responsibility.

\section{CONCLUSION}

Visum et repertum can be used as legitimate evidence in criminal cases against animals which is supported by the regulations that are in effect in Indonesia.

\section{SUGGESTIONS}

The discussion regarding the formal law procedures in criminal procedures about the verification of crimes against animals needs some augmentation relating to aspects which might be different to the verification of crimes against humans.

\section{REFERENCES}

1. Hakim , Lukman Nul. 2014. PERANAN VISUM ET REPERTUM PADA TAHAP PENYIDIKAN DALAM MENGUNGKAP TINDAK PIDANA KEJAHATAN PENGANIAYAAN. FAKULTAS HUKUM UNIVERSITAS MUHAMMADIYAH SURAKARTA

2. Harahap, M.Yahya. 2001. Pembahasan Permasalahan Dan Penerapan KUHAP (Jilid I)., Jakarta : Pustaka Kartini, Hal 54.

3. Johnson, Olivia. Dog Fighting and the Growing Social Epidemic of Animal Cruelty. The Journal of Law Enforcement Vol.3. ISSN: 2161-0231 (Online). 
4. KUHP , Moeljatno, Bumi Akasara, 1996

5. KUHAP, Soenarto Soerodiboto, Raja Grafindo Persada, 1991

6. Liuw,Yesika.2015. Perlindungan Hukum Terhadap Hewan Lindung Menurut Undang-Undang Nomor 5 Tahun 1990. lex Crimen Vol. Iv/No. 3/Mei/2015
7. Sasangka,Hari and Lili Rosita, Hukum Pembuktian Dalam Perkara Pidana, Penerbit Mandar Maju , Bandung, 2003, hal. 60.

8. Tjiptomartono Agung Legowo, 1982, Penerapan Ilmu Kedokteran Kehakiman Dalam Proses Penyidikan, Jakarta: Karya Unipres, hal. 1. 